\title{
The Sulphate Effect on Lijiaxia Concrete Dam (China) Gallery
}

\author{
Xufen Zhu, ${ }^{1} \mathrm{Ji} \mathrm{Li}^{2}{ }^{2}$ Yi Zhang, ${ }^{2}$ Hanzhou Song, ${ }^{1}$ and Hu Zheng ${ }^{1}$ \\ ${ }^{1}$ School of Earth Science and Engineering, Hohai University, Nanjing 210098, China \\ ${ }^{2}$ Yellow River Upstream Hydropower Limited Liability Company, Xining 810008, China \\ Correspondence should be addressed to Hu Zheng; zhenghu@hhu.edu.cn
}

Received 27 April 2017; Accepted 3 August 2017; Published 3 October 2017

Academic Editor: Petros Gikas

Copyright (C) 2017 Xufen Zhu et al. This is an open access article distributed under the Creative Commons Attribution License, which permits unrestricted use, distribution, and reproduction in any medium, provided the original work is properly cited.

\begin{abstract}
The concrete degradation is one of the most serious problems for a dam construct during the normal operation, which determines the dam service life. Hence, it is very important to reduce the extent of the dam concrete degradation for the safety of the dam normal operation. Here, Lijiaxia hydroelectric station is taken as an example, and a comprehensive method to assess the sulphate effect on dam gallery is proposed. Eleven samples in total were taken from three difference locations by the drill bore. The microstructural investigations including X-ray fluorescence spectrometry (XRF), X-ray diffraction (XRD), scanning electron microscope (SEM), and energy dispersive spectroscopy (EDS) were conducted to assess the sulphate attack and the degradation degree. Meanwhile, the water chemical analysis was applied to reveal the mechanism of concrete degradation. The experimental and analysis results indicate that the concrete degradation degree varies with the location of the samples. The components of the concrete change and the content of $\mathrm{SO}_{3}$ increase dramatically during degradation. Moreover, the mineral facies of the concrete change correspondingly, with the cement paste substituted by the calcite, calcium vitriol, and gypsum. The reinforcement and precaution measures are suggested based on the results of the degradation assessment.
\end{abstract}

\section{Introduction}

Lots of hydropower stations were constructed along the Yangtze River and Yellow River in China from 1950s, especially in the southwestern China [1-3]. Meanwhile, the concrete dams have to be built on the rivers with the hydropower stations. Most of the concrete dams have been working for decades, and the concrete degradation would happen with time [4]. Concrete degradation is mainly attached by reactive liquids and gases, which could cause the chemical, colloidal, or physicochemical deterioration and disintegration of solid concrete components and structures [5]. The degradation process would lead to the concrete weight loss and surface spalling $[6,7]$. There are several different reasons causing concrete degradation, including salt water or acidic ground water, microbes in sewer pipes, sulphates, chlorides, nitrates, fluorides, sulphides, and industrial waste like slag and corrosive gases and so on $[5,8]$. The combination of the factors mentioned above leads to concrete degradation, while the concrete structures are exposed to an aggressive environment. Sulphates effect is one of the most ubiquitous ones in the natural environment, but the mechanism of sulphate attack on cement concrete is not well understood [9]. This has limited the confidence to the assessment of degradation degree, which is the main factor of the dam stability. Hence, a systematic research effort on sulphate effect is necessary to the safety of dam construction and the normal operation of the hydropower station.

The sulphate concrete degradation inspection and evaluation have attracted much scientific attention in recent years $[10,11]$ (Hu et al. 2016). Many different methods for the concrete degradation assessment were proposed $[12,13]$. For example, a borehole could be drilled in the concrete dam, and the core would be taken out to check the concrete degradation degree. The drilled core method is one of the most common methods because the inside of the concrete could be revealed and exposed directly by this method. Moreover, the concrete core could be used as the samples of laboratory tests [14]. Some other methods, including indentation method, rebound method, and ultrasonic method, are also applied to the dam concrete degradation examination [15]. However, almost all of the methods mentioned above could only provide the macroscopically evaluation results and qualitatively describe the degradation phenomena of the dam 


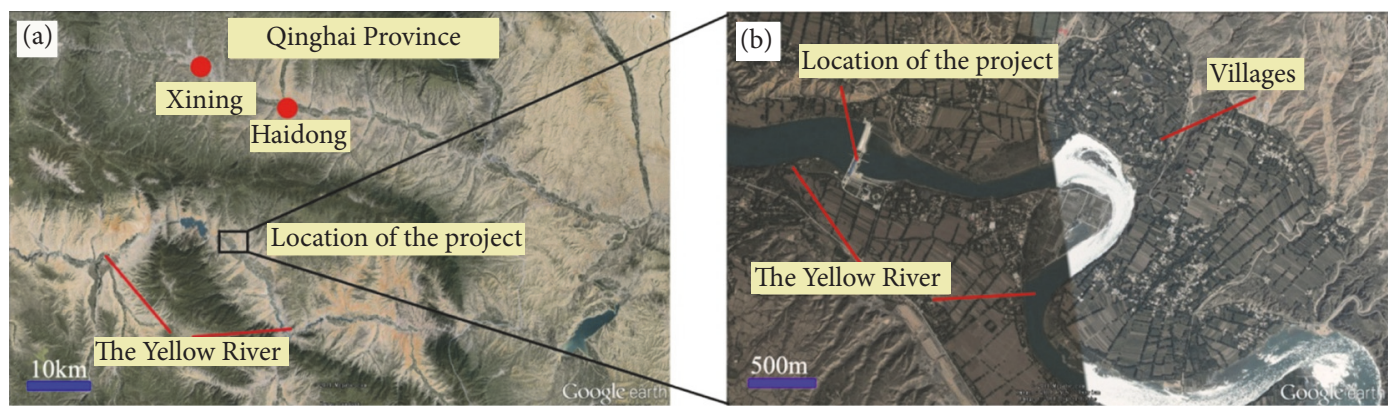

Figure 1: Map showing location of the project: Lijiaxia hydropower station (satellite image from Google Earth).

concrete. The substantial mechanism of concrete degradation could not be understood because the precipitations after the degradation are varying.

Recently, several researchers have studied the concrete dam degradation based on the microstructural investigations, such as XRF, XRD, SEM, and EDS [16, 17]. Romer and Lienemann [18] presented the deterioration of shotcrete in the safety gallery by the salt-containing water based on the XRF and XRD microstructural measurements. Hu et al. [19] have shown that the concrete of Yongan Dam is deteriorated due to the thaumasite form of sulphate attack, according to microanalytical investigations, SEM and energy disperse Xray (EDX). Portella et al. [14] analyzed the elemental chemical composition and phases of a concrete dam with over 50 years of operation by EDS and XRD techniques. However, most of the microanalytical studies on the dam concrete degradation are based on single or two experimental techniques, which might cause the local uncertainty of the precipitations.

In this paper, both in situ investigations and a series of laboratory tests including XRF, XRD, SEM, and EDS were conducted to analyze the sulphate attach degradation of Lijiaxia hydroelectric station dam gallery concrete. Comprehensive concrete degradation analysis was done based on the field investigations and laboratory tests results. At the end, the precaution measures were suggested to control the dam gallery concrete degradation. The research results could provide useful information for future inspections for Lijiaxia hydroelectric station dam and regular inspections for other similar concrete dams.

\section{Study Areas}

Lijiaxia hydropower station is located in Jainca County, Qinghai Province, China, which is the third step hydropower station of upper reaches of the Yellow River (Figure 1). The dam is a concrete arch-gravity dam with length $414.39 \mathrm{~m}$ and height $515 \mathrm{~m}$. The dam houses a hydroelectric power station with $5 \times 400 \mathrm{MW}$ generators for a total installed capacity of 2,000 MW. The hydropower station is the second largest hydropower station in the northwestern of China, which is the pivotal role for the electricity generating and irrigation in this area. Moreover, there are many people living in villages at the downstream of the dam. Hence, the stability of the river dam is very important to the normal operations of the hydropower station and the safety of the people living at downstream.

The schematic of the hydropower station dam gallery and the location details of sampling are shown in Figure 2. The field investigation shows that the worst location of degradation is BH3 (elevation: 2038); the degradation degree of the surface concrete is dramatic. Lots of local apophysis and desquamate phenomena could be seen on the concrete step at the $\mathrm{BH} 3$ position. Conversely, the degradation degrees of the surface concrete around the $\mathrm{BH} 1$ and $\mathrm{BH} 2$ are not that terrible. Only several local apophysis and desquamate phenomena could be found on the step (Figure 2). Three concrete samples beside the three boreholes and eight concrete samples from different depths of borehole cores were taken. The depth details of each borehole core sample are shown in Table 1. In order to clarify the mechanism of this dam gallery concrete degradation, several laboratory tests including XRF, $\mathrm{XRD}, \mathrm{SEM}$, and EDS were conducted to inspect the concrete degradation and degradation degree of the concrete for both borehole and gallery surface samples.

\section{Chemical Constituents Detecting of Degradation Concrete}

3.1. XRF Experiments and Results. The XRF tests were conducted on all samples from three locations to investigate the basic chemical composition. X-ray fluorescence (XRF) is the emission of fluorescent X-rays from a material that has been excited by bombarding with high-energy X-rays or gamma rays. The phenomenon is widely used for building materials and for research in geochemistry, forensic science, and archaeology [20,21]. Both of the major constituents and trace components can be detected by the XRF test. According to the XRF test results, the chemical constituents and loss on ignitions (LOI) of the concrete samples are shown in Tables 2 and 3 , respectively.

The chemical compositions of all 8 concrete samples are very close. The basic elements are $\mathrm{Si}, \mathrm{Al}, \mathrm{Ca}$, and $\mathrm{Fe}$, (Table 2). The site survey results also indicate that all of these samples are fairly intact (Figure 2). The average LOI value is $11.24 \%$, and average mass fraction percentage of $\mathrm{SiO}_{2}$ is $45 \%$ and that of $\mathrm{SO}_{3}$ is only $0.91 \%$. The LOI values of the samples have very good positive correlation with the mass fraction percentage of $\mathrm{CaO}$ (Figure 3), which indicates that the LOI of the concrete is 


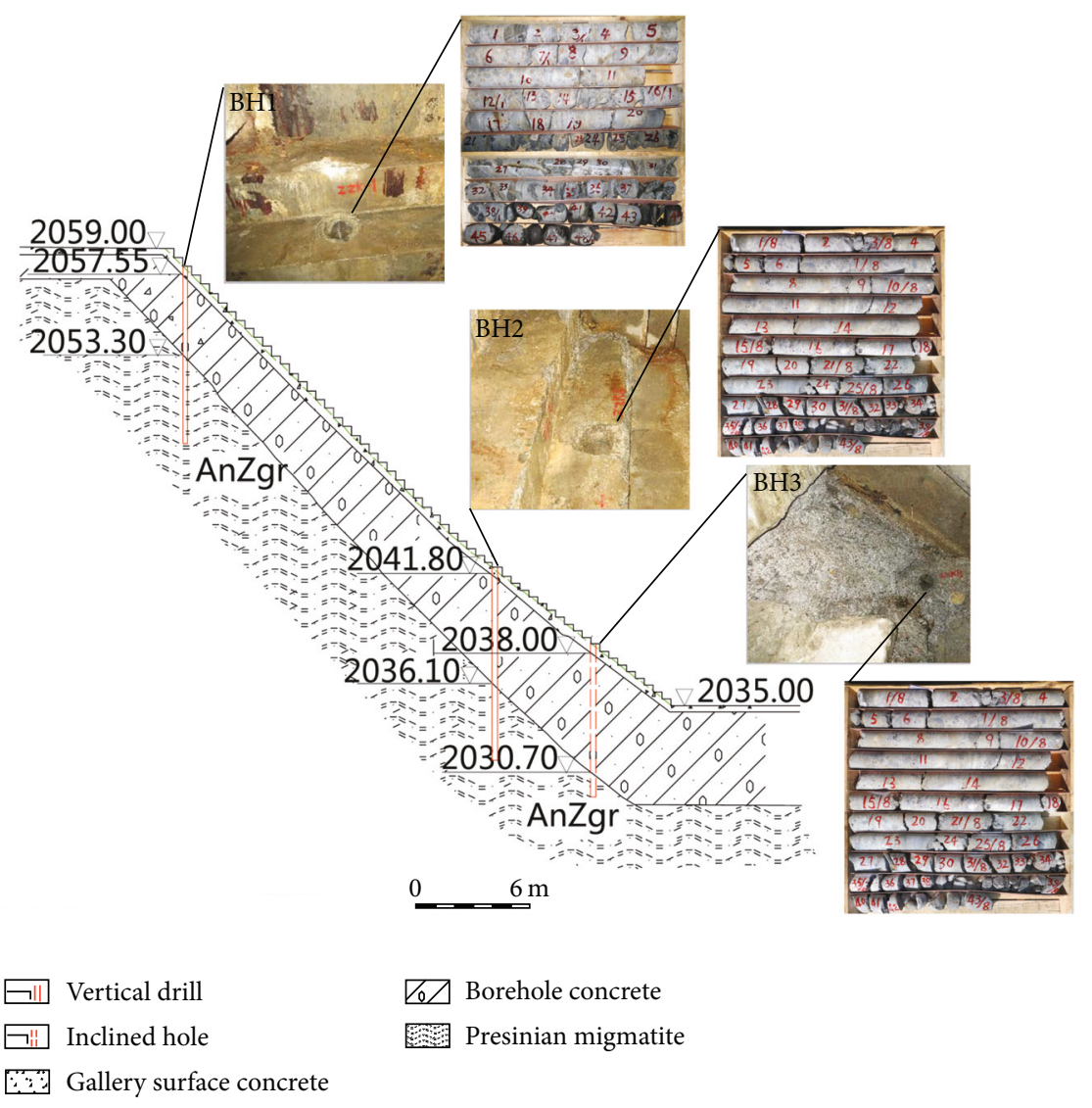

FIgURE 2: The details of the sampling locations and the concrete corrosion photos.

TABLE 1: The number and depth of the samples.

\begin{tabular}{lcc}
\hline Number of borehole & Number of samples & Depth of the sample position \\
\hline & BH1-0 & 0 \\
BH1 & BH1-1 & $0.45 \mathrm{~m}$ \\
& BH1-2 & $1.30 \mathrm{~m}$ \\
& BH1-3 & $3.25 \mathrm{~m}$ \\
& BH1-4 & $4.35 \mathrm{~m}$ \\
\hline & BH2-0 & 0 \\
& BH2-1 & $0.40 \mathrm{~m}$ \\
& BH2-2 & $5.70 \mathrm{~m}$ \\
BH3 & BH3-0 & 0 \\
& BH3-1 & $0.60 \mathrm{~m}$ \\
& BH3-2 & $6.90 \mathrm{~m}$ \\
\hline
\end{tabular}

mainly caused by $\mathrm{CaO}$ decomposing and the organic content is very small.

Three concrete samples from the dam gallery surface, which are in serious degradation according to the site survey (Figure 2), were also taken to do the XRF test. The average LOI value is $21.76 \%$, which means there are lots of materials lost at $1000-1100^{\circ} \mathrm{C}$ heat for the degradation concrete of the dam gallery surface. The average mass fraction percentages of $\mathrm{SiO}_{2}$ are only $17.43 \%$, which is less than half of that of borehole samples. Nevertheless, the average mass fraction percentage of $\mathrm{SO}_{3}$ reaches $33.38 \%$.
The comparison of chemical constituents and LOI between surface and borehole concrete samples is shown in Figure 3. The main differences between seriously corroded concrete, taken from the gallery surface, and fairly intact concrete are the $\mathrm{SiO}_{2}, \mathrm{CaO}, \mathrm{Al}_{2} \mathrm{O}_{3}$, and $\mathrm{SO}_{3}$ contents. For the fairly intact concrete, the contents of $\mathrm{SiO}_{2}$ and $\mathrm{Al}_{2} \mathrm{O}_{3}$ are more than those of degradation concrete. Conversely, the contents of $\mathrm{CaO}$ and $\mathrm{SO}_{3}$ of fairly intact concrete are less than those of degradation concrete. All the above test results indicate that the concrete degradation at Lijiaxia dam gallery concrete belongs to sulphate attack. In order to analyze 
TABLE 2: The basic element compositions of the concrete samples from boreholes.

\begin{tabular}{lcccccccccccc}
\hline \multirow{2}{*}{ Number } & \multirow{2}{*}{$\mathrm{LOI}$} & $\mathrm{SiO}_{2}$ & $\mathrm{Al}_{2} \mathrm{O}_{3}$ & $\mathrm{CaO}$ & $\mathrm{Fe}_{2} \mathrm{O}_{3}$ & $\mathrm{~K}_{2} \mathrm{O}$ & $\mathrm{SO}_{3}$ & $\mathrm{Na}_{2} \mathrm{O}$ & $\mathrm{MgO}$ & $\mathrm{TiO}_{2}$ & $\mathrm{MnO}^{2}$ & $\mathrm{Cl}$ \\
\hline BH1-1 & 12.80 & 42.66 & 11.06 & 22.72 & 4.22 & 1.42 & 1.07 & 1.13 & 2.10 & 0.45 & 0.07 & 0.02 \\
BH1-2 & 11.17 & 44.34 & 12.28 & 19.29 & 4.82 & 2.19 & 0.72 & 1.24 & 3.05 & 0.51 & 0.08 & 0.02 \\
BH1-3 & 11.34 & 42.86 & 11.56 & 21.20 & 5.20 & 1.81 & 0.89 & 1.41 & 2.81 & 0.52 & 0.09 & 0.02 \\
BH1-4 & 5.54 & 53.92 & 13.16 & 11.06 & 6.37 & 3.39 & 0.47 & 1.57 & 3.36 & 0.75 & 0.11 & 0.02 \\
BH2-1 & 17.02 & 34.69 & 7.45 & 31.43 & 3.19 & 1.13 & 1.72 & 0.86 & 1.76 & 0.31 & 0.05 & 0.14 \\
BH2-2 & 12.26 & 43.33 & 11.70 & 21.42 & 3.90 & 2.18 & 1.15 & 1.38 & 1.91 & 0.41 & 0.06 & 0.04 \\
BH3-1 & 9.73 & 50.25 & 13.93 & 13.30 & 5.01 & 2.14 & 0.54 & 1.66 & 2.47 & 0.57 & 0.09 & 0.01 \\
BH3-2 & 10.06 & 47.94 & 12.78 & 15.91 & 4.68 & 1.94 & 0.69 & 1.51 & 3.58 & 0.50 & 0.09 & 0.03 \\
Average & 11.24 & 45.00 & 11.74 & 19.54 & 4.67 & 2.03 & 0.91 & 1.35 & 2.63 & 0.50 & 0.08 & 0.04 \\
\hline
\end{tabular}

TABLE 3: The basic element compositions of the concrete samples from gallery surface.

\begin{tabular}{|c|c|c|c|c|c|c|c|c|c|c|c|c|}
\hline \multirow{2}{*}{ Number } & \multirow{2}{*}{ LOI } & \multicolumn{11}{|c|}{ Chemical compositions (\%) } \\
\hline & & $\mathrm{SiO}_{2}$ & $\mathrm{Al}_{2} \mathrm{O}_{3}$ & $\mathrm{CaO}$ & $\mathrm{Fe}_{2} \mathrm{O}_{3}$ & $\mathrm{~K}_{2} \mathrm{O}$ & $\mathrm{SO}_{3}$ & $\mathrm{Na}_{2} \mathrm{O}$ & $\mathrm{MgO}$ & $\mathrm{TiO}_{2}$ & $\mathrm{MnO}$ & $\mathrm{Cl}$ \\
\hline BH1-0 & 24.17 & 19.10 & 4.37 & 32.92 & 3.00 & 0.41 & 10.82 & 0.39 & 4.17 & 0.25 & 0.05 & 0.09 \\
\hline $\mathrm{BH} 2-0$ & 20.34 & 17.54 & 3.38 & 33.27 & 2.50 & 0.36 & 20.07 & 0.35 & 1.55 & 0.19 & 0.04 & 0.21 \\
\hline BH3-0 & 20.76 & 15.65 & 3.15 & 33.94 & 2.31 & 0.37 & 22.20 & 0.23 & 0.92 & 0.15 & 0.04 & 0.12 \\
\hline Average & 21.76 & 17.43 & 3.63 & 33.38 & 2.60 & 0.38 & 17.70 & 0.32 & 2.21 & 0.20 & 0.04 & 0.14 \\
\hline
\end{tabular}

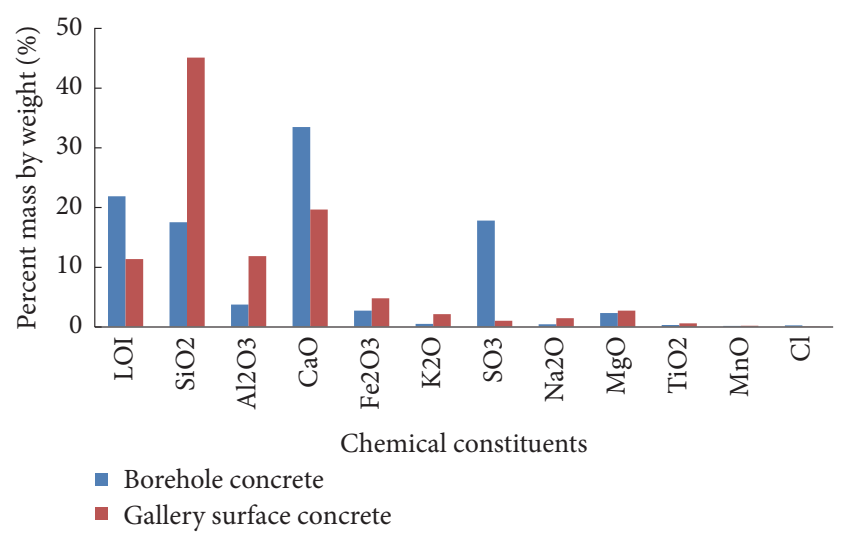

FIGURE 3: The comparison XRF tests results between gallery surface and borehole concrete specimens.

the degradation products of the concrete, XRD tests were conducted to investigate the main mineral facies of all the concrete samples.

3.2. The Main Mineral Facies Analysis by XRD. XRD is an effective tool for identifying the atomic and molecular structures of a crystal. The crystalline atoms can cause a beam of incident X-rays to diffract into many specific directions. The crystallographer can produce a three-dimensional picture of the density of electrons within the crystal according to the angles and intensities of these diffracted beams. Hence, the mean positions of the atoms in the crystal, chemical bonds, and disorder can be determined [22-24]. All of the 11 samples were subjected to XRD tests to investigate the elements fabric, existing state, and the mineral facies $[18,19]$.
Similar XRD tests results of the borehole samples were obtained from the three difference locations (Figure 4). However, the gallery surface samples vary with the borehole samples, even though they are from the same location. The main reason might be that the degradation degrees are different, which also could be found by the site survey and XRF test results. The $\mathrm{SiO}_{2}$ and $\mathrm{CaCO}_{3}$ are the main matters of the samples, including surface and borehole samples, where the $\mathrm{SiO}_{2}$ is from the concrete aggregate, while $\mathrm{CaCO}_{3}$ indicates that the carbonization happened in the concrete. The main difference between the borehole concrete and gallery surface is the set cement which is composed of the hydrated cement products, such as $\mathrm{Ca}(\mathrm{OH})_{2}$. The set cement could not be found in the seriously corroded gallery surface samples by the XRD test but was found in the borehole samples. The difference confirms that samples from gallery surface have been eroded in the corrosive medium environment. Moreover, the $\mathrm{CaSO}_{4} \cdot 0.5 \mathrm{H}_{2} \mathrm{O}$ were detected in the samples from $\mathrm{BH} 2-0$ and $\mathrm{BH} 3-0$ locations, which is the typical mineral of the concrete degradation by the sulphate solution $[17,25]$. The $\mathrm{CaSO}_{4} \cdot 0.5 \mathrm{H}_{2} \mathrm{O}$ mineral shows that the concrete degradations from $\mathrm{BH} 2-0$ and $\mathrm{BH} 3-0$ are the most severe locations among all 11 samples.

Another interesting thing found from the XRD spectra result is that the ettringite might exist in $\mathrm{BH} 1-3$ and $\mathrm{BH} 1-4$ samples $(2 \theta=8.75, d=9.97 \sim 10.11)$ (Figure 4$)$. In order to make it clear whether the ettringite exists as the degradation products, SEM and EDS tests were conducted on BH1-3 and BH1-4 samples.

3.3. The SEM and EDS Tests. Both SEM and EDS tests were conducted in the Center of Modern Analysis Nanjing University, China. The SEM tests were conducted by a Hitachi 

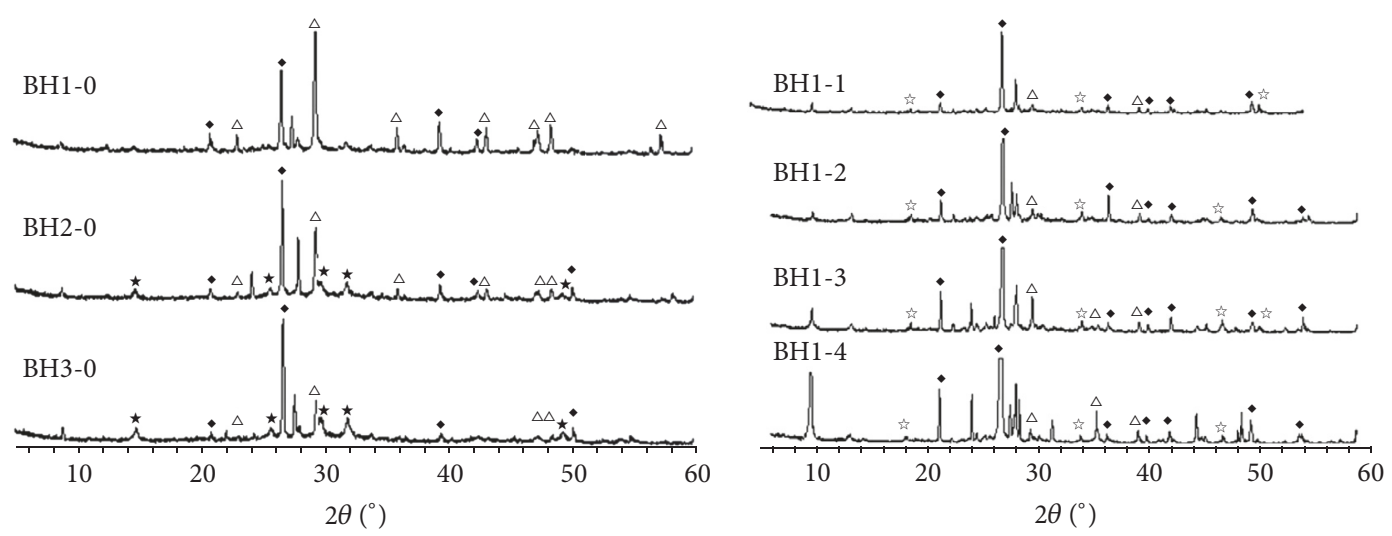

- $\mathrm{SiO}_{2}$

- $\mathrm{SiO}_{2}$

$\triangle \mathrm{CaCO}_{3}$

$\star \mathrm{CaSO}_{4} \cdot 0.5 \mathrm{H}_{2} \mathrm{O}$

$\triangle \mathrm{CaCO}_{3}$

\& $\mathrm{Ca}(\mathrm{OH})_{2}$

(a)

(b)

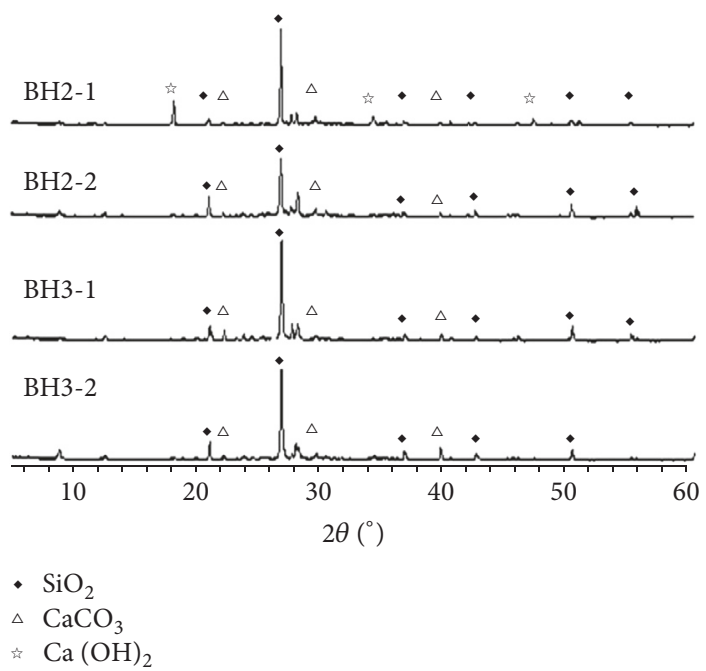

(c)

FIGURE 4: The XRD spectrum results: (a) the gallery surface; (b) samples from BH1; (c) samples from BH2 and BH3.

S-3400N II scanning electron microscope, and the SEM images of BH1-3 and BH1-4 samples are shown in Figure 5. The relative concentration rod-like crystalline contents could be seen in both of two samples, which is very similar to the crystal shape of ettringite $\left(3 \mathrm{CaO} \cdot \mathrm{Al}_{2} \mathrm{O}_{3} \cdot 3 \mathrm{CaSO}_{4} \cdot 32 \mathrm{H}_{2} \mathrm{O}\right)$ [17].

Meanwhile, the EDS spectra results are shown in Figure 6 , which indicate that the major elements of the rodlike crystalline contents and the adjacent mineral are $\mathrm{Ca}$, $\mathrm{S}$, and $\mathrm{Al}$. The corresponding oxides of $\mathrm{Ca}, \mathrm{S}$, and $\mathrm{Al}$ are $\mathrm{CaO}, \mathrm{SO}_{3}$, and $\mathrm{Al}_{2} \mathrm{O}_{3}$, and the total mass contents of these oxides are $91.86 \%$ and $95.80 \%$ for $\mathrm{BH} 1-3$ and $\mathrm{BH} 1-4$ samples, respectively. Moreover, $\mathrm{Ca}, \mathrm{S}$, and $\mathrm{Al}$ are the basic elements of ettringite, and the total contents of the corresponding oxides are over $90 \%$. Hence, it is confirmed that the ettringite mineral is generated in the $\mathrm{BH} 1[17,25,26]$, which is the typical sulphate attack product. Hence, proper precautions have to be taken on this hydropower station dam gallery, especially for the sulphate attack prevention.

\section{The Mechanism of Concrete Degradation}

The above tests results indicate that the dam gallery concrete of the Lijiaxia hydropower station dam was subjected to degradation damage to some extent, especially by the sulphate attack, not only for the surface concrete. In order to investigate the mechanism of the concrete degradation, the water samples were collected from the three different boreholes. The water quality tests were operated for each of the samples, and the results are shown in Table 4. The contents of $\mathrm{SO}_{4}{ }^{2-}$ are more than $1000 \mathrm{mg} / \mathrm{L}$ in the water from three boreholes, which could corrode the ordinary Portland cement but not sulphate resistant one. However, the content of $\mathrm{SO}_{4}{ }^{2-}$ is more than $3000 \mathrm{mg} / \mathrm{L}$ in $\mathrm{BH} 2$, which indicates that even sulphate resistant cement could get degradation.

There are not only $\mathrm{Ca}^{2+}$ and $\mathrm{SO}_{4}{ }^{2-}$ existing in the concrete groundwater, but also some other ions. However, the other ions would affect the position of the critical saturation point due to the ion effect. The saturation indexes (SI) between 


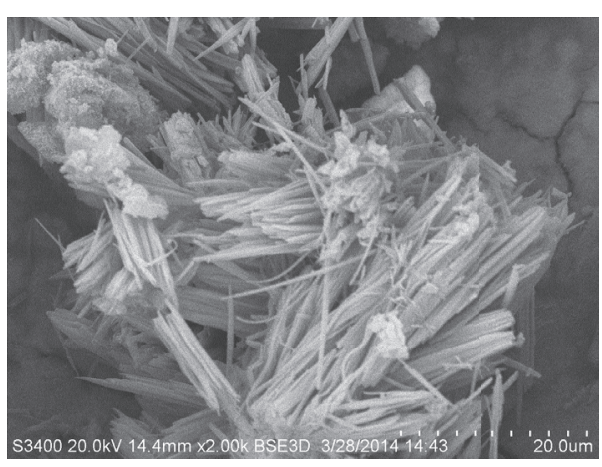

(a)

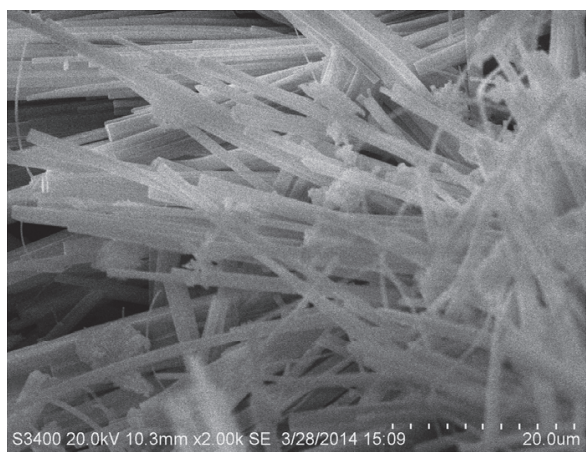

(b)

FIGURE 5: The SEM images of the concrete samples from BH1: BH1-3 (a) and BH1-4 (b) sample.

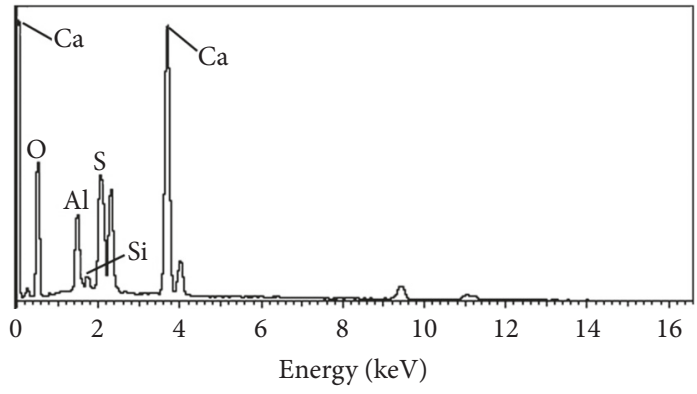

(a)

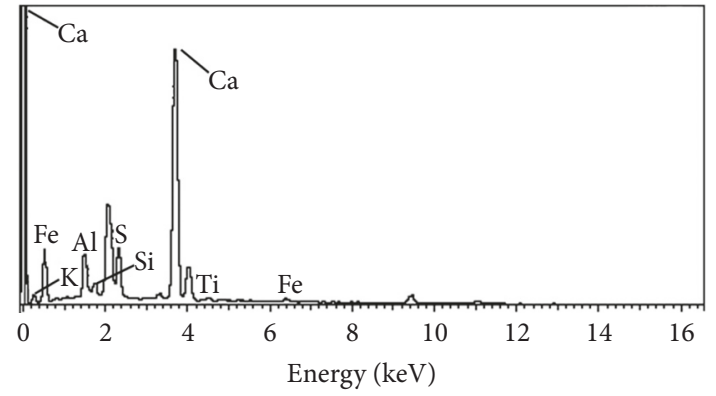

(b)

FIGURE 6: The EDS spectra of the concrete samples from BH1: (a) BH1-3 sample; (b) BH1-4 sample.

carbonates [15], sulphates, and the groundwater from these three boreholes were analyzed (Table 5). The analyzed results show that $\mathrm{SI}>0$ between sulphates and the groundwater from $\mathrm{BH} 2$ and $\mathrm{BH} 3$, which means the mineral is precipitating, while SI $<0$ for BH1, which means the mineral is dissolved. SI $>0$ between carbonates and the groundwater of all three boreholes, which means the concrete is being corroded and the mineral is precipitating. All of the concrete from the three locations could get degradation, and some new substance might be generated in the view of the chemical thermodynamics. In sulphate environment, the $\mathrm{SO}_{4}{ }^{2-}$ would have chemical reaction with $\mathrm{Ca}(\mathrm{OH})_{2}$ in concrete to form $\mathrm{CaSO}_{4}$ firstly, and then $\mathrm{CaSO}_{4}$ would have chemical reaction with hydrated calcium aluminate or monosulfate to form ettringite $\left(3 \mathrm{CaO} \cdot \mathrm{Al}_{2} \mathrm{O}_{3} \cdot 3 \mathrm{CaSO}_{4} \cdot 32 \mathrm{H}_{2} \mathrm{O}\right)$. The reaction formulas are shown in the following:

$$
\begin{gathered}
4 \mathrm{CaO} \cdot \mathrm{Al}_{2} \mathrm{O}_{3} \cdot 19 \mathrm{H}_{2} \mathrm{O}+2 \mathrm{Ca}(\mathrm{OH})_{2}+3 \mathrm{SO}_{4}{ }^{2-}+14 \mathrm{H}_{2} \mathrm{O} \longrightarrow 3 \mathrm{CaO} \cdot \mathrm{Al}_{2} \mathrm{O}_{3} \cdot 3 \mathrm{CaSO}_{4} \cdot 32 \mathrm{H}_{2} \mathrm{O}+6 \mathrm{OH}^{-} \\
3 \mathrm{CaO} \cdot \mathrm{Al}_{2} \mathrm{O}_{3} \mathrm{CaSO}_{4} \cdot 18 \mathrm{H}_{2} \mathrm{O}+2 \mathrm{Ca}(\mathrm{OH})_{2}+2 \mathrm{SO}_{4}{ }^{2-}+14 \mathrm{H}_{2} \mathrm{O} \longrightarrow 3 \mathrm{CaO} \cdot \mathrm{Al}_{2} \mathrm{O}_{3} \cdot 3 \mathrm{CaSO}_{4} \cdot 32 \mathrm{H}_{2} \mathrm{O}+4 \mathrm{OH}^{-}
\end{gathered}
$$

However, $\mathrm{Ca}(\mathrm{OH})_{2}$ and $\mathrm{CaSO}_{4}$ in the concrete could form gypsum with a high concentration of $\mathrm{SO}_{4}{ }^{2-}$ :

$$
\begin{gathered}
\mathrm{Ca}(\mathrm{OH})_{2}+\mathrm{SO}_{4}{ }^{2-}+2 \mathrm{H}_{2} \mathrm{O} \longrightarrow \mathrm{CaSO}_{4} 2 \mathrm{H}_{2} \mathrm{O}+2 \mathrm{OH}^{-} \\
3 \mathrm{CaO} \cdot 2 \mathrm{SiO}_{2} \cdot 3 \mathrm{H}_{2} \mathrm{O}+3 \mathrm{SO}_{4}{ }^{2-}+8 \mathrm{H}_{2} \mathrm{O} \longrightarrow 3\left(\mathrm{CaSO}_{4} \cdot 2 \mathrm{H}_{2} \mathrm{O}\right)+6 \mathrm{OH}^{-}+2 \mathrm{SiO}_{2} \cdot \mathrm{H}_{2} \mathrm{O}
\end{gathered}
$$

Both the microstructural investigation results and water quality analysis show that the Lijiaxia concrete dam gallery is subjected to concrete degradation, especially by sulphate attack. The proper reinforcement and precaution measures 
TABLE 4: The statistic results of the hydrochemical characteristics from three boreholes.

\begin{tabular}{lcccccc}
\hline Locations & $\mathrm{SO}_{4}{ }^{2-}(\mathrm{mg} / \mathrm{L})$ & $\mathrm{HCO}_{3}{ }^{-}(\mathrm{mmol} / \mathrm{L})$ & $\mathrm{pH}$ & $\mathrm{TDS}(\mathrm{mg} / \mathrm{L})$ & Hardness $(\mathrm{meq} / \mathrm{L})$ & $\mathrm{Categories}$ \\
\hline $\mathrm{BH} 1$ & 1253.00 & 0.02 & 11.50 & 2723.34 & 18.73 & $\mathrm{SO} \cdot \mathrm{Cl}-\mathrm{Ca} \cdot \mathrm{Na}$ \\
$\mathrm{BH} 2$ & 3225.00 & 0.08 & 9.35 & 6031.75 & 51.83 & $\mathrm{SO} \cdot \mathrm{Cl}-\mathrm{Ca} \cdot \mathrm{Na}$ \\
$\mathrm{BH} 3$ & 2102.00 & 0.02 & 11.49 & 4334.61 & 35.54 & $\mathrm{SO} \cdot \mathrm{Cl}-\mathrm{Ca} \cdot \mathrm{Na}$ \\
\hline
\end{tabular}

TABLE 5: The saturation index (SI) of the groundwater from the three boreholes.

\begin{tabular}{lccccrrr}
\hline Location & $\mathrm{CaCO}_{3}$ & $\mathrm{CaSO}_{4}: 2 \mathrm{H}_{2} \mathrm{O}$ & $\mathrm{CaMg}\left(\mathrm{CO}_{3}\right)_{2}$ & $\mathrm{Na}_{2} \mathrm{SO}_{4}$ & $\mathrm{Na}_{2} \mathrm{SO}_{4}: 10 \mathrm{H}_{2} \mathrm{O}$ & $\mathrm{MgSO}_{4}: 7 \mathrm{H}_{2} \mathrm{O}$ & $\mathrm{K}_{2} \mathrm{SO}_{4}$ \\
\hline $\mathrm{BH} 1$ & 1.60 & -0.27 & 1.41 & -9.30 & -8.54 & -7.70 & -8.86 \\
$\mathrm{BH} 2$ & 1.13 & 0.25 & 1.05 & -6.55 & -5.80 & -6.59 & -8.42 \\
$\mathrm{BH} 3$ & 1.69 & 0.04 & 1.63 & -6.94 & -6.18 & -7.36 & -8.72 \\
\hline
\end{tabular}

have to be conducted to limit further degradation and make sure the safety of dam construction. Firstly, the dam gallery surface concrete is corroded seriously, which has to be reinforced. According to the water quality analysis results, the sulphate resistant concrete is suggested to be used in the reinforcement. In addition, the drainage holes in the gallery are suggested to be checked over to clarify whether they are effectively plugged or not. The plugged drainage holes have to be cleared to restore the water drainage function, which could decrease the alternate dry and wet of the gallery concrete.

\section{Conclusions}

The degradation of the concrete dam is one of the most important issues after the hydropower station is built. A reasonable and correct method is the key role of the concrete degradation evaluation. In this paper, the comprehensive evaluation method by using XRF, XRD, SEM, and EDS is applied on the gallery concrete of Lijiaxia hydropower station. In this paper, the experimental method of dam concrete degradation assessment could be a useful reference for future inspections for Lijiaxia hydroelectric station dam and regular inspections for other similar concrete dams. Our experimental study has made the following findings.

(1) Both of the gallery surface and borehole concrete are corroded. The degradation degree of gallery surface concrete is much more severe than the borehole concrete. But the degradation is not enough to cause harm to the hydropower station. The surface concrete is suggested to be reinforced by the sulphate resistant concrete based on experimental results.

(2) The main chemical composition contents of the concrete change during the degradation, and the $\mathrm{SO}_{3}$ content increases obviously as the degradation degree increases. Moreover, the mineral facies of the concrete change correspondingly, and the set cement would be replaced by calcite and ettringite, which indicates that the concrete is subjected to the sulphate attack.

\section{Conflicts of Interest}

The authors declare that they have no conflicts of interest.

\section{Acknowledgments}

This work was supported by the National Natural Science Foundation of China (Grant no. 41272265), the NSF (Jiangsu, China) (Grant no. BK20140845), the China Postdoctoral Science Foundation (Grant no. 2014M561567), and the Fundamental Research Funds for the Central Universities of China (Grant no. 2014B03414).

\section{References}

[1] F. T. Zhang, Y. J. Duan, S. M. Cao, J. W. Wang, and D. Q. Tan, "High genetic diversity in population of Lepturichthys fimbriata from the Yangtze River revealed by microsatellite DNA analysis," Chinese Science Bulletin, vol. 57, no. 5, pp. 487491, 2012.

[2] L. Zhang, D. X. Yang, Y. W. Liu, Y. T. Che, and D. J. Qin, "Impact of impoundment on groundwater seepage in the Three Gorges Dam in China based on CFCs and stable isotopes," Environmental Earth Sciences, vol. 72, no. 11, pp. 4491-5000, 2014.

[3] B.-R. Chen, Q.-P. Li, X.-T. Feng, Y.-X. Xiao, G.-L. Feng, and L.$\mathrm{X}$. Hu, "Microseismic monitoring of columnar jointed basalt fracture activity: a trial at the Baihetan Hydropower Station, China," Journal of Seismology, vol. 18, no. 4, pp. 773-793, 2014.

[4] J. Li, X. Liang, X. Mao, and H. Peng, "Geochemical analysis on educts in the drainage corridor of a big dam over Yangtze River," Journal of Earth Science, vol. 23, no. 2, pp. 180-186, 2012.

[5] I. Biczók and N. Blasovszky, "Concrete corrosion and concrete protection," Chemical Publishing Company, 1964, New York.

[6] K. A. T. Vu and M. G. Stewart, "Structural reliability of concrete bridges including improved chloride-induced corrosion models," Structural Safety, vol. 22, no. 4, pp. 313-333, 2000.

[7] G. Dhinakaran, S. Thilgavathi, and J. Venkataramana, "Compressive strength and chloride resistance of metakaolin concrete," KSCE Journal of Civil Engineering, vol. 16, no. 7, pp. 12091217, 2012.

[8] R. Tichý, P. Lens, J. T. C. Grotenhuis, and P. Bos, "Solid-state reduced sulfur compounds: Environmental aspects and bioremediation," Critical Reviews in Environmental Science and Technology, vol. 28, no. 1, pp. 1-40, 1998.

[9] P. Richard and MH. Cheyrezy, "Reactive powder concretes with high ductility and 200-800 MPa compressive strength," ACI Special Publication, vol. 144, pp. 10-14359, 1994. 
[10] O. Poupard, V. L'Hostis, S. Catinaud, and I. Petre-Lazar, "Corrosion damage diagnosis of a reinforced concrete beam after 40 years natural exposure in marine environment," Cement and Concrete Research, vol. 36, no. 3, pp. 504-520, 2006.

[11] B. Ma, X. Gao, E. A. Byars, and Q. Zhou, "Thaumasite formation in a tunnel of Bapanxia Dam in Western China," Cement and Concrete Research, vol. 36, no. 4, pp. 716-722, 2006.

[12] S.-S. Kim and S.-T. Lee, "Microstructural observations on the deterioration of concrete structure for sewage water treatment," KSCE Journal of Civil Engineering, vol. 14, no. 5, pp. 753-758, 2010.

[13] Z. Liu, G. De Schutter, D. Deng, and Z. Yu, "Micro-analysis of the role of interfacial transition zone in "salt weathering" on concrete," Construction and Building Materials, vol. 24, no. 11, pp. 2052-2059, 2010.

[14] K. F. Portella, A. Joukoski, V. Swinka Filho, M. A. Soares, and E. S. Ferreira, "Physical chemistry research of a concrete dam with over 50 years of operation," Ceramica, vol. 58, no. 347, pp. 374-380, 2012.

[15] H. Z. Song, Environmental hydrogeology around dam-site, China WaterPower Press, Beijing, China, 2007.

[16] F. Goetz-Neunhoeffer, J. Neubauer, and P. Schwesig, "Mineralogical characteristics of ettringites synthesized from solutions and suspensions," Cement and Concrete Research, vol. 36, no. 1, pp. 65-70, 2006.

[17] W.-Y. Ouyang, J.-K. Chen, and M.-Q. Jiang, "Evolution of surface hardness of concrete under sulfate attack," Construction and Building Materials, vol. 53, pp. 419-424, 2014.

[18] M. Romer and P. Lienemann, "Deterioration of shotcrete in the safety gallery of the gotthard motorway tunnel by saltcontaining water," Chimia, vol. 52, no. 5, pp. 197-201, 1998.

[19] M. Y. Hu, F. M. Long, and M. S. Tang, "The thaumasite form of sulfate attack in concrete of Yongan Dam," Cement and Concrete Research, vol. 36, no. 10, 2006.

[20] E. P. Bertin, Principles and Practice of X-Ray Spectrometric Analysis, Kluwer Academic/Plenum Publishers, Boston, Mass, USA, 1979.

[21] B. Beckhoff, h. B. Kanngießer, N. Langhoff, R. Wedell, and H. Wolff, Handbook of Practical X-Ray Fluorescence Analysis, Springer Berlin Heidelberg, Berlin, Heidelberg, 2007.

[22] W. H. Bragg and W. L. Bragg, "The structure of the diamond," in Proceedings of the Royal Society of London, Series A, Containing Papers of a Mathematical and Physical Character, vol. 91, p. 557, London, UK, 1913.

[23] W. L. Bragg, R. James, and C. Bosanquet, "The distribution of electrons around the nucleus in the sodium and chlorine atoms," Philosophical Magazine, vol. 44, no. 261, pp. 433-449, 1922.

[24] B. Rupp and J. Wang, "Predictive models for protein crystallization," Methods, vol. 34, no. 3, pp. 390-407, 2004.

[25] J.-K. Chen and M.-Q. Jiang, "Long-term evolution of delayed ettringite and gypsum in Portland cement mortars under sulfate erosion," Construction and Building Materials, vol. 23, no. 2, pp. 812-816, 2009.

[26] B. G. Ma, "Sulfate resistance mechanism of high-performance concrete containing NCI," Journal Wuhan University of Technology, vol. 4, no. 1, pp. 6-15, 1999. 

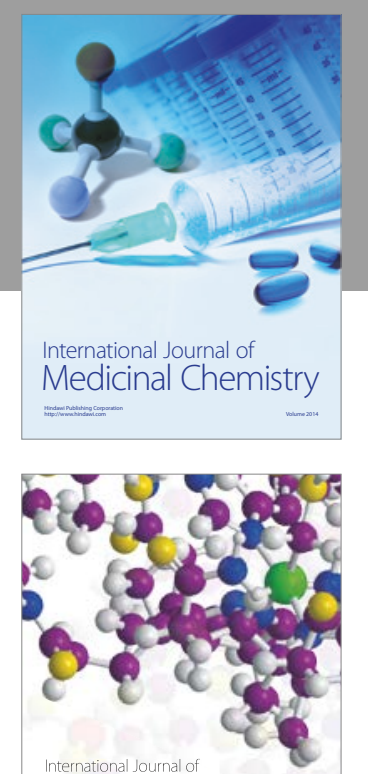

Carbohydrate Chemistry

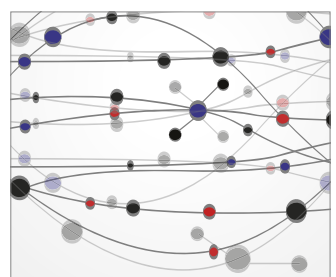

The Scientific World Journal
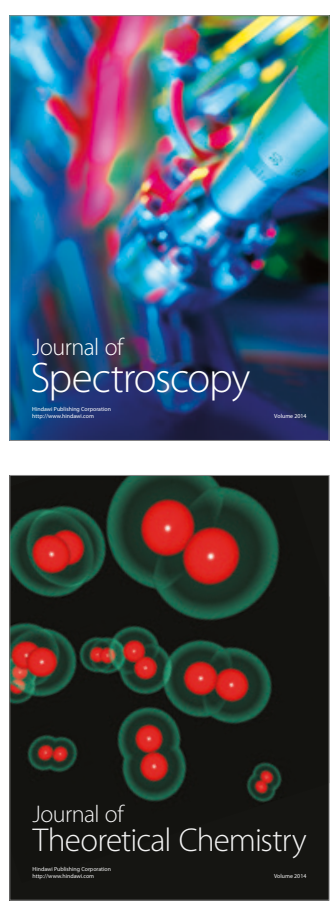
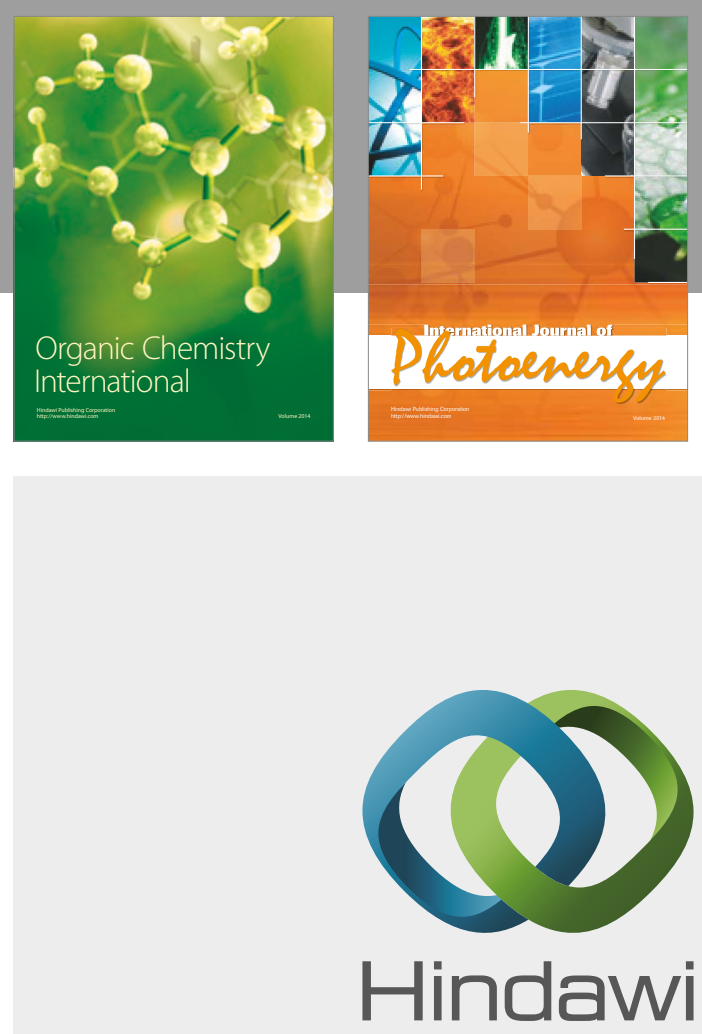

Submit your manuscripts at

https://www.hindawi.com

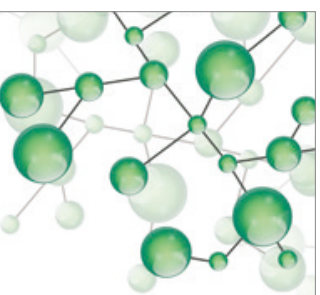

International Journal of

Inorganic Chemistry

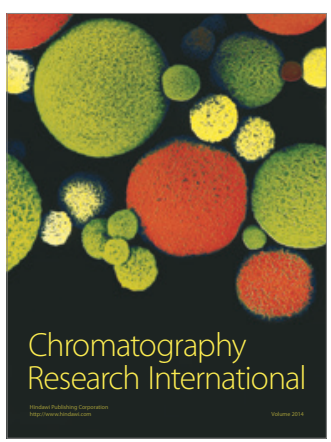

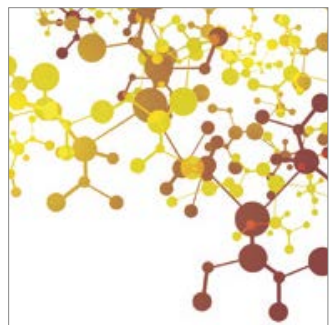

Applied Chemistry
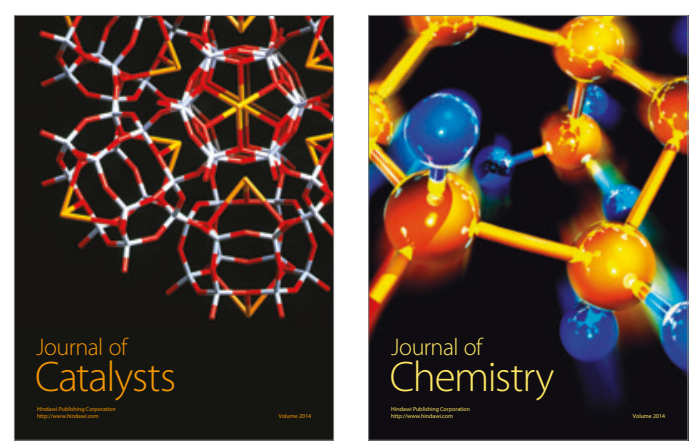
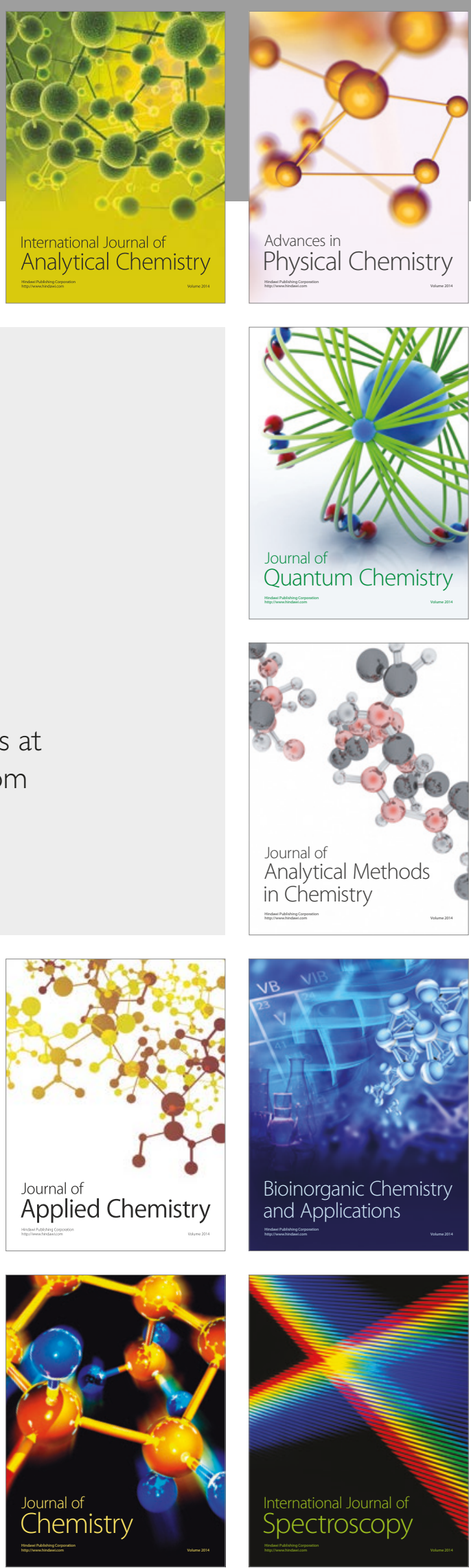